\title{
Nitrogen fertilization and spacing in productivity and quality of passion fruit implanted with advanced seedlings
}

\author{
Gabriel Stefanini Mattar ${ }^{1}$, Luís Felipe Villani Purquerioº ${ }^{2}$ Laura Maria Molina Meletti ${ }^{2}$, \\ Sílvia Regina de Toledo Valentini ${ }^{3}$, Laís Fernanda de Paula4, Adriana Modolon Duart ${ }^{4}$ \begin{abstract}
number of thousand fruits per hectare, respectively, $20.7 \mathrm{t} \mathrm{ha}^{-1}$ and 139.5 thousand fruits ha-1.
\end{abstract} \\ Abstract-The use of advanced seedlings associated with the annual cultivation of passion fruit are \\ important management techniques for living with the fruit-hardening virus (FEV). However, this \\ technology still needs information on nitrogen fertilization and spacing between plants, so that it is \\ possible to recover crop's productivity. The objective of this research was to identify the nitrogen \\ dose $(\mathrm{N})$ and the most suitable spacing for annual orchards installed with advanced seedlings $(1.2$ \\ $\mathrm{m}$ high) of yellow passion fruit. The experiment was carried out in the field, in Mogi Mirim, SP, \\ between October 2017 and July 2018. A randomized block design was used in subdivided plots; \\ the treatments were doses of $\mathrm{N}$ in coverage such as $0,60,120,180$ and $240 \mathrm{~kg} \mathrm{ha}^{-1}$ and spacing \\ between plants of 2.0 and $4.0 \mathrm{~m}$ and $3.0 \mathrm{~m}$ between lines. The dose found for maximum production, \\ $15.4 \mathrm{~kg}$ of fruit $\mathrm{pl}^{-1}$, and adequate physical-chemical quality of the fruit for the yellow passion fruit \\ was $130.7 \mathrm{~kg} \mathrm{ha}^{-1}$ of $\mathrm{N}$. The most densified spacing, of $2 \times 3 \mathrm{~m}$, provided greater productivity and \\ Index terms: Passiflora edulis Sims, plant nutrition, plant density, annual cycle, production system.

\section{Adubação nitrogenada e espaçamento na produtividade e qualidade do maracujá-azedo implantado com mudas avançadas}

\section{Corresponding author: gabriel.mattar@uol.com.br \\ Received: January 28, 2021 Accepted: June 17, 2021}

Copyright: All the contents of this journal, except where otherwise noted, is licensed under a Creative Commons Attribution License.

\section{(cc) $\mathbf{E Y}$}

Resumo -A utilização de mudas avançadas, associadas ao cultivo anual do maracujazeiro, é técnica importante de manejo para a convivência com o vírus do endurecimento dos frutos (VEF). No entanto, esta tecnologia ainda necessita de informações sobre adubação nitrogenada e espaçamento entre plantas, para que seja possível recuperar a produtividade da cultura. O objetivo desta pesquisa foi identificar a dose de nitrogênio $(\mathrm{N})$ e o espaçamento mais adequado para pomares anuais instalados com mudas avançadas $(1,2 \mathrm{~m}$ de altura) de maracujá-azedo. O experimento foi realizado a campo, em Mogi Mirim-SP, entre outubro de 2017 e julho de 2018. Utilizou-se do delineamento de blocos casualizados em parcelas subdivididas, sendo os tratamentos doses de $\mathrm{N}$ em cobertura com $0 ; 60 ; 120 ; 180$ e $240 \mathrm{~kg} \mathrm{ha}^{-1}$ e espaçamentos entre plantas de 2,0 e 4,0 m e 3,0 m nas entrelinhas. A dose encontrada para máxima produção, de $15,4 \mathrm{~kg}$ de fruto $\mathrm{pl}^{-1}$, e adequada qualidade físico-química do fruto pelo maracujá-azedo foi de $130,7 \mathrm{~kg} \mathrm{ha}^{-1} \mathrm{de} \mathrm{N}$. O espaçamento mais adensado, de $2 \times 3 \mathrm{~m}$, proporcionou maior produtividade e número de mil frutos por hectare, sendo, respectivamente, de 20,7 tha $\mathrm{ta}^{-1} 39,5$ mil frutos $\mathrm{ha}^{-1}$.

Termos para indexação: Passiflora edulis Sims, ciclo anual, densidade de planta, nutrição de plantas, sistema de produção.

\footnotetext{
${ }^{1} \mathrm{PhD}$ in the Postgraduate Program Tropical and Subtropical Agriculture, Instituto Agronômico (IAC), Campinas-SP, Brazil. E-mail: gabriel.mattar@uol.com.br(ORCID 0000-0002-7175-9597)

${ }^{2} \mathrm{PhD}$, Researcher at Instituto Agronômico (IAC) - Horticulture Center, Campinas-SP, Brazil. E-mail: lauramolina27@gmail. com; felipe.purquerio@sp.gov.br (ORCID 0000-0002-2962-4517)

${ }^{3} \mathrm{PhD}$, Researcher at Instituto Agronômico (IAC) - Biophysical Ecophysiology Center, Campinas-SP, Brazil. E-mail: valentini@ iac.sp.gov.br ${ }^{\text {(ORCID 0000-0003-0614-4999) }}$

${ }^{4}$ M.Sc., in the Postgraduate Program in Tropical and Subtropical Agriculture at Instituto Agronômico (IAC), Campinas-SP, Brazil. E-mail: 1fpaula14@gmail.com (ORCID 0000-0002-3135-2733);driamd@hotmail.com (ORCID 0000-0003-2125-4213)
} 


\section{Introduction}

Brazil stands out in the world production and consumption of passion fruit (Passiflora edulis Sims) and is the largest producer with $593,429 \mathrm{t}$ with a cultivated area of 41,800 ha, however, the national average productivity of $14.2 \mathrm{t} \mathrm{ha}^{-1}$ is considered low (IBGE, 2019). In addition to the low technological level used in the culture, several diseases cause losses in production and fruit quality.

Currently, the hardening fruit virus (HFV), the Cowpea aphid-borne mosaic virus (CABMV), causes the greatest damage and is present in most producing regions. It is also one of the main causes of $48.6 \%$ reduction in the cultivated area in the State of São Paulo since 1995 (NASCIMENTO et al., 2006; YUKI et al., 2006; DAMATTO JUNIOR et al., 2014). In 2019, the State of São Paulo produced 30,809 t of fruit in 1,885 ha, making it the fourth largest producer state (IBGE, 2019). Infected plants have their production reduced both quantitatively and qualitatively, as the fruits become smaller, deformed and hardened, the aggressiveness of this disease has made production unfeasible, making the crop itinerant and annual (GIORIA et al., 2000; NARITA et al., 2012).

In view of the delays of breeding programs to obtain genetic resistance, the inefficiency of chemical control and the absence of defensive registered for the crop, among techniques for coexistence with the viruses, there is a recommendation to replace the traditional seedlings production system, which facilitates early infection by high or advanced seedlings (1.2 $\mathrm{m}$ high). These are produced in agricultural greenhouse with anti-aphid roof, which avoids the entry of the virus insect vector, the aphid, and consequently the contamination and dispersion of HFV (CAVICHIOLI et al., 2014). However, this technology still needs more studies, especially regarding the density of planting and fertilization, since the culture has become annual in areas with viruses (DAMATTO JUNIOR et al., 2014). According to this same author, the passion fruit has production potential of 30 to $35 \mathrm{tha}^{-1}$, when all recommended agronomic techniques are correctly applied, much higher than the current Brazilian average (14.2 t $\mathrm{ha}^{-1}$ ) (IBGE, 2019).

In recent years the crop has also undergone several modifications in its production technology, such as planting varieties and hybrids that are more productive, with potential of $50 \mathrm{t} \mathrm{ha}^{-1}$ year-1 $^{-1}$ (MELETTI, 2011), as well as reducing spacing. Thus, plant nutrition needs to be adequate to these new management techniques, aiming at maximum productive response as well as fruit quality (FURLANI and PURQUERIO, 2010; MIYAKE et al., 2016).
However, although nitrogen $(\mathrm{N})$ is the most extracted nutrient and the second most exported (HAAG et al., 1973; MATTAR et al., 2018) the recommended $\mathrm{N}$ amount for the crop varies between 94 and $235 \mathrm{~kg}$ ha $^{-1}$ year $^{-1}$ (RIPADO, 2010; MIYAKE et al., 2018). In addition, studies showed variable responses on $\mathrm{N}$ effect on fruit quality as well as nutritional studies in area with the presence of HFV, the performance evaluation of advanced seedlings in the field on $\mathrm{N}$ doses effect and its correlation with productivity are scarce (AULAR et al., 2014; MIYAKE et al., 2018; BERTANI et al., 2019). This lack of information hinders the elaboration of a precise recommendation to the rural producer, which can harm the activity productivity recovery.

Currently, seeking the great utilization of the areas cultivated with fruit trees, the strategy to reduce spacing to increase the number of plants per area and maximization of productivity, has been practiced throughout the national territory (ARAÚJO NETO et al., 2005; WEBER et al., 2016; MIYAKE et al., 2018). Several studies with passion fruit plant, demonstrated the increase in productivity with the highest density (ANDRADE et al., 1994; MANICA et al., 1994; ANDRADE JÚNIOR et al., 2003; WEBER et al., 2016). However, there are few studies in the literature that evaluated the development, production and quality of fruits in dense orchards implanted with advanced seedlings and annual cultivation, since this management can be an alternative to recover productivity in areas affected by the virus.

Considering that Brazil is the largest producer of passion fruit and that the culture demands intense labor, it is an alternative of income source for family agriculture. Then the objective of this study was to evaluate passion fruit development, production and quality of fruit according to nitrogen dose applied in coverage, and also meeting the other recommendations of macro and micronutrients applied to the soil, as well as orchard spacing implanted with advanced seedlings in annual cultivation, which should assist in the recovery of passion fruit productivity in the state of São Paulo.

\section{Material and Methods}

The experiment was conducted in the field in the municipality of Mogi Mirim, SP, between October 11, 2017 and end of July 2018 , in the coordinates $22^{\circ} 32^{\prime} 55^{\prime \prime}$ $\mathrm{S}$ and $46^{\circ} 57^{\prime} 19^{\prime \prime} \mathrm{O}$, altitude of $645 \mathrm{~m}$, in a Red-yellow Oxisol (SANTOS et al., 2018). The climate is classified as Cwa (Köppen), subtropical dry winter climate and hot summer. Previously, in this area passion fruit was cultivated followed by a year of landing. The data of soil chemical attributes, at 0-20 $\mathrm{cm}$, before the preparation of the experimental area are shown in Table 1. The chemical analysis followed the methodology proposed by Raij et al. (2001). 
Table 1. Soil chemical attributes, at $0-20 \mathrm{~cm}$, of the experimental area before the preparation of the experimental area. Mogi Mirim, SP, 2017.

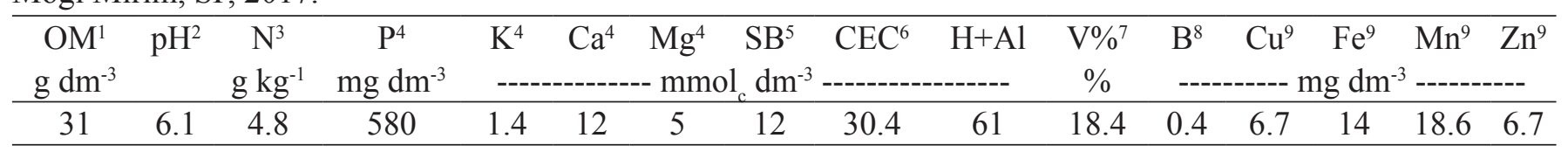

${ }^{1}$ Organic matter; ${ }^{2} \mathrm{pH} \mathrm{CaCl} 20.01 \mathrm{~mol} \mathrm{~L}-1 ;{ }^{3} \mathrm{~N}_{\text {total }}$, Kjeldahl method; ${ }^{4}$ resin extraction; ${ }^{5}$ Sum of bases (Calculation); ${ }^{6}$ cation exchange capacity;

${ }^{7}$ base saturation; ${ }^{8}$ hot water extraction; ${ }^{9}$ DTPA extraction.

The data of average temperature and maximum, mean and minimum relative humidity and precipitation per month, are shown in Figure 1A and 1B. Climatic data were collected from the meteorological station located in Mogi Mirim, which comprise the network of Integrated Center of Agrometeorological Information (Ciiagro).
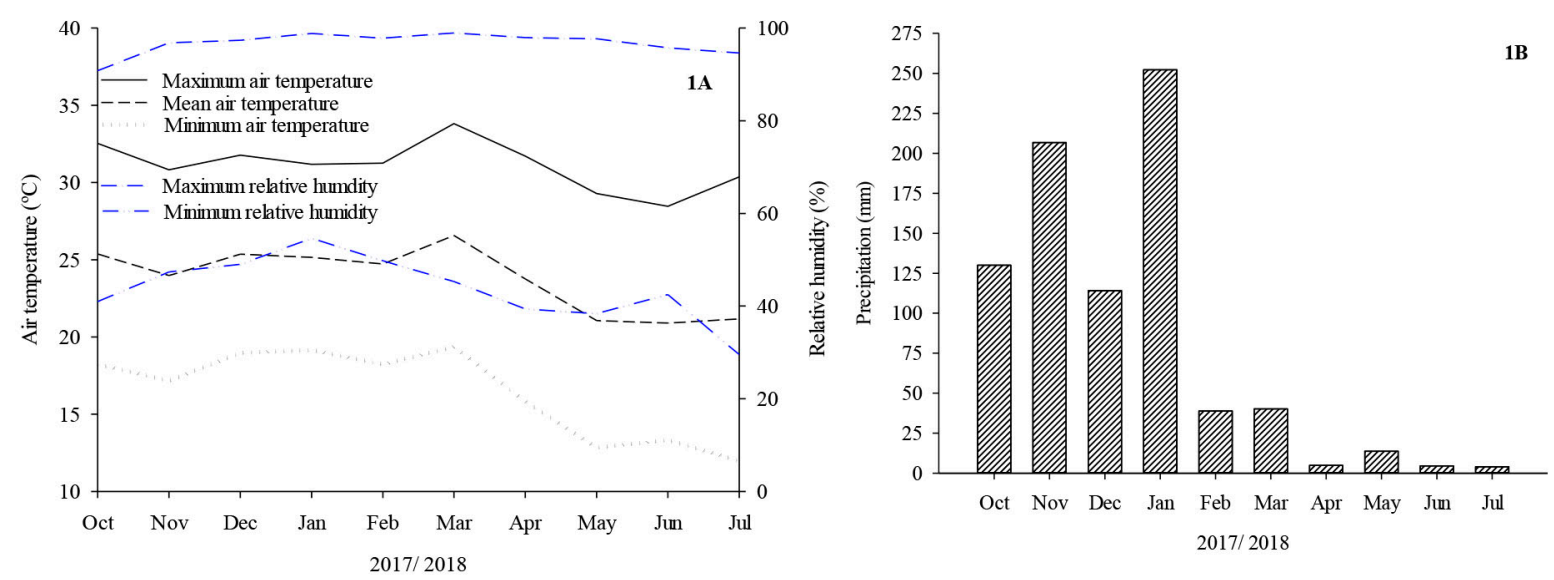

Figure 1. Maximum, mean and minimum temperature and relative humidity (Figure 1A) and precipitation per month (Figure 1B) of the experimental area. Mogi Mirim, SP, October 2017 to July 2018.

The experimental design was randomized block in a scheme of subdivided plots and four replications. Each subplot was composed of three plants. The main treatment was composed of nitrogen $(\mathrm{N})$ doses in coverage at 0,60 , 120,180 and $240 \mathrm{~kg} \mathrm{ha}^{-1}$, corresponding to $0,50,100$, 150 and $200 \%$ of the production fertilization of $120 \mathrm{~kg}$ ha $^{-1}$ of N, recommended by Piza Junior et al. (1997) for an expected productivity of 25 to $30 \mathrm{tha}^{-1}$ for traditional cultivation. The secondary treatment was the spacing between plants of 2.0 and $4.0 \mathrm{~m}$ and fixed between lines at $3.0 \mathrm{~m}$. Advanced seedlings were used with $1.2 \mathrm{~m}$ high and the annual cultivation technique, the orchard was implanted in 10/11/2017 and eradicated in 07/30/2018, respecting the period of sanitary emptiness.

The production of passion fruit advanced seedlings occurred in protected cultivation structure, covered with low-density polyethylene (LDPE), $150 \mathrm{~mm}$ thick, laterally closed with anti-aphid screen. The IAC-10 cultivar sowing occurred in 03/01/2017, it was performed in germination paper, and subsequently, the subculture was transferred for plastic bags measuring $0.25 \times 0.50 \mathrm{~m}$. The substrate used was a mixture of Tropstrato $\mathrm{HA}^{\circledR}$ (pinus bark, vermiculite, $\mathrm{PG}$ mix ${ }^{\mathrm{TM}} 14-16-18, \mathrm{KNO}_{3}, \mathrm{P}_{2} \mathrm{O}_{5}$ and peat), pinus bark and tanned cattle manure, in the ratio of 1:1:2.
The fertilization of plant formation, usually performed in the field, was carried out in the seedlings according to the recommendation of Piza Junior et al (1997), with application in each plant of $10 \mathrm{~g}$ of $\mathrm{N} 30$ days after transplantation to the plastic bag, $15 \mathrm{~g}$ of $\mathrm{N}$ after 60 days, $50 \mathrm{~g}$ of $\mathrm{N}$ and $50 \mathrm{~g}$ of $\mathrm{K}_{2} \mathrm{O}$ after 90 days, using ammonia sulfate and potassium chloride.

In the experimental area, liming with dolomitic limestone was performed 45 days before transplantation, in order to raise the base saturation to $80 \%$ and the magnesium to a minimum content of $9 \mathrm{mmol}_{\mathrm{c}} \mathrm{dm}^{-3}$. The holes, $0.3 \times 0.3 \times 0.3 \mathrm{~m}$, were prepared with $0.75 \mathrm{~kg}$ of Yoorin Master ${ }^{\circledR}\left(16 \% \mathrm{P}_{2} \mathrm{O}_{5}\right), 0.5 \mathrm{~kg}$ of dolomitic limestone and 8 liters of chicken manure following recommendation of Piza Junior et al (1997). Chemical data of the chicken manure used are shown in Table 2, according to the methodology proposed by Abreu et al. (2006). 
Table 2. Chemical analysis of chicken manure used in the preparation of passion fruit planting holes. Mogi Mirim, SP, 2017.

\begin{tabular}{|c|c|c|}
\hline $\begin{array}{l}\text { N-total } \\
\text { g kg-1 }^{1}\end{array}$ & $\mathrm{~N}-\mathrm{NO}_{3}{ }^{-2}$ & $\mathrm{~N}-\mathrm{NH}_{4}^{+2}$ \\
\hline 84.9 & 45.3 & 356.6 \\
\hline
\end{tabular}

${ }^{1}$ Kjeldahl method; ${ }^{2} \mathrm{KCl}$ extraction.

The seedlings transplantation to the field occurred in 10/11/2017, 224 days after sowing, when the coverage fertilizations with $\mathrm{N}$ (ammonium nitrate source, $32 \%$ of $\mathrm{N}$ and $1 \%$ of $\mathrm{K}_{2} \mathrm{O}$ ) started, for the application of the treatments. $\mathrm{N}$ doses were applied between November/17 and May/18 and the relative quantities varied according to the need of the crop (MATTAR et al., 2018). These were $10 ; 22.5 ; 22.5 ; 22.5 ; 22.5 \%$ of the total $\mathrm{N}$ at $36 ; 97 ; 134$; 167; 218 days after transplantation (DAT) respectively. The coverage with the other nutrients were performed for an expected productivity of 25-30 $\mathrm{t} \mathrm{ha}^{-1}$, applying $50 \mathrm{~kg}$ $\mathrm{ha}^{-1}$ of $\mathrm{P}_{2} \mathrm{O}_{5}, 280 \mathrm{~kg} \mathrm{ha}^{-1}$ of $\mathrm{K}_{2} \mathrm{O}, 2 \mathrm{~kg} \mathrm{ha}^{-1}$ of B and $4 \mathrm{~kg}$ $\mathrm{ha}^{-1}$ of Zn, (PIZA JUNIOR et al, 1997), in the same period and proportions of $\mathrm{N}$ fertilization.

The conducting system was vertical espalier, with a wire at $2.0 \mathrm{~m}$ of soil height. After transplantation, the plants were tutored with narrow plastic ribbon until the height of the wire, in a single rod. Then the top trimming occurred, for the emission of the secondary and opposite lateral branches, which suffered pruning to originate the productive curtain (tertiary branches).

To avoid water stress and ensure the greater utilization of the applied fertilizer, the soil moisture was monitored by means of an Irrigas ${ }^{\circledR}$ equipment set, using the $25 \mathrm{kPa}$ capsules installed at depth of 0.25 and $0.50 \mathrm{~m}$ and in four points of the experimental area. The irrigation was performed when necessary, using drip irrigation system, with drips every $20 \mathrm{~cm}$. During the experiment period, were also carried out hoeing, pest and diseases control, manual pollination and fruit collection.

At 34 DAT the length of the primary rod (LPR), number of primary branch leaves (NPBL), primary rod diameter (PRD) were evaluated. At 64 DAT, the secondary branch length (SBL), the number of primary rod leaves plus the secondary branch (NPRLSB) and the primary rod diameter (PRD) were measured. At 132 DAT was evaluated the length of the tertiary branch (LTB), the number of tertiary branch leaves (NTBL) and the primary rod diameter (PRD). For the LTB and NTBL an average of three representative branches per plant was calculated.

To quantify the production, a weekly harvest and the sum of the fruits collected throughout the experiment was performed. Thus, the production $\left(\mathrm{kg} \mathrm{pl}^{-1}\right)$ and the number of fruits per plant (NFP) (n. fruit $\mathrm{pl}^{-1}$ ) were obtained. From these data, the productivity $\left(\mathrm{t} \mathrm{ha}^{-1}\right)$ and the number of thousand fruits per hectare $(\mathrm{NThFH})$ (n. thousand fruits $h^{-1}$ ) were calculated. Disposing the fruits with deformation, stains, or disease symptoms, the percentage of commercial fruits (\%) (CEAGESP, 2001) was obtained.

For the evaluations of the fruit physical characteristics, six fruits per plot were used, in monthly evaluations and an average of these values were calculated. In the physical analysis of the fruit, the following was determined: mass (g); transversal length (TL), longitudinal (LL) $(\mathrm{cm})$ and pulp yield (\%). The pulp yield was calculated as follows: [(aryl mass + seed $) /$ total fruit mass] x100. Through the TL the fruit caliber was classified, following the CEAGESP (2001) classification standards. The same six fruits were used to determine the following chemical characteristics: the juice soluble solid content (SS) expressed in ${ }^{\circ}$ Brix, determined by portable digital refractometer Pocket Refractometer, PAL-1, Atago; juice total titratable acidity (TTA) (\% of citric acid), 10 $\mathrm{g}$ of the juice plus $90 \mathrm{~mL}$ of distilled water, titration with sodium hydroxide $(\mathrm{NaOH}) 0.1 \mathrm{~N}$ to $\mathrm{pH} 8.1$; the $\mathrm{pH}$ was determined by direct reading of the juice samples in a digital potentiometer; the SS/TTA (Ratio) ratio; the juice ascorbic acid content (AAC) (mg of ascorbic acid per 100 g), determined according to IAL (2008) methodology.

The data were analyzed using the variance analysis and by means of the F test. When there was significance for the $\mathrm{N}$ doses, regression analysis was performed, defining the best adjustment according to the significance combination and the higher coefficient of determination using the SigmaPlot program. When there was a significant effect for the spacing, the Tukey test $(\alpha=0.05 \%)$ was applied to compare the treatments means.

\section{Results and discussion}

There was no interaction between the nitrogen (N) doses and the spacing between plants as well as the isolated effect of the $\mathrm{N}$ for the vegetative development characteristics in the passion fruit. It was found that the plants submitted to $4.0 \mathrm{~m}$ spacing, had higher secondary branch length (SBL), number of primary stem and secondary branch leaves (NPSSBL), primary stem diameter (PSD) at 64 days after transplantation (DAT), respectively, $116.2 \mathrm{~cm}, 52.9$ leaves and $8.2 \mathrm{~mm}$ (Table 3). At 132 DAT, the PSD was also higher in the $4.0 \mathrm{~m}$ spacing, measuring $14.1 \mathrm{~mm}$. 
At 34 DAT the mean value of the primary stem length (PSL) was $187.6 \mathrm{~cm}$, the number of primary stem leaves (NPSL) was 24.6, the primary stem diameter (PSD) was $5.5 \mathrm{~mm}$, while the tertiary branch length (TBL) and the number of tertiary branch leaves (NTBL) were 161.7 $\mathrm{cm}$ and 19.2, respectively, at the 132 DAT.
In Adamantina, SP, with traditional grafted seedlings, Nasser et al. (2011) evaluating the planting line spacing $1.0 ; 1.5 ; 2.0 ; 3.0 ; 4.0$ and $5.0 \mathrm{~m}$; and $3.2 \mathrm{~m}$ between lines, also found lower SBL when they used $1.5 \times 3.2 \mathrm{~m}$ between plants, with $139.1 \mathrm{~cm}$, differing from the 3.0 and $4.0 \mathrm{~m}$ spacing, with 191.0 and $189.8 \mathrm{~cm}$, respectively. These authors also observed higher PSD with the use of less dense spacing, $4.0 \times 3.2 \mathrm{~m}, 30.4 \mathrm{~mm}$ compared to 1.0 x $3.2 \mathrm{~m}$ and $2.0 \times 3.2 \mathrm{~m}$, respectively, 22.75 and $24.5 \mathrm{~mm}$ at 360 days after transplantation (DAT).

Table 3. Secondary branch length (SBL) and number of primary stem and secondary branch leaves (NPSSBL) at 64 days after transplantation (DAT) and primary stem diameter (PSD) at 64 and 132 DAT depending on the spacing between passion fruit plants, 2.0 and 4.0 m between plants and 3.0 between lines. Mogi Mirim, SP, October 2017 to July 2018.

\begin{tabular}{|c|c|c|c|c|}
\hline Spacing & $\begin{array}{c}\text { SLB } \\
64 \text { DAT }\end{array}$ & $\begin{array}{l}\text { NPSSBL } \\
64 \text { DAT }\end{array}$ & $\begin{array}{c}\text { PSD } \\
64 \text { DAT }\end{array}$ & $\begin{array}{c}\text { PSD } \\
132 \mathrm{DAT}\end{array}$ \\
\hline $\mathrm{m}$ & $\mathrm{cm}$ & --- & $\mathrm{mm}$ & $\mathrm{mm}$ \\
\hline 2 & $84.7 b$ & $48.5 b$ & $7.9 b$ & $12.9 \mathrm{~b}$ \\
\hline 4 & $116.2 \mathrm{a}$ & $52.9 \mathrm{a}$ & $8.2 \mathrm{a}$ & $14.1 \mathrm{a}$ \\
\hline $\mathrm{dms}$ & 11.7 & 3.5 & 0.22 & 0.64 \\
\hline$\overline{\mathrm{CV} \%}$ & 17.38 & 10.31 & 4.11 & 7.11 \\
\hline
\end{tabular}

Column means, followed by the same letter, do not differ from each other by Tukey test at $5 \%$ probability.

Using traditional seedlings and evaluating the development of grafted passion fruit, Cavichioli et al. (2011) reported superior SBL value, $337.4 \mathrm{~cm}$ at 150 days after sowing (DAS) and the primary stem diameter of $30.6 \mathrm{~mm}$ at 360 DAS on an ungrafted plant. Possibly, in addition to the difference of seedling type and transplantation period that allows great plant development period in the field. These authors used even greater spacing, the traditional is $5.0 \times 3.2 \mathrm{~m}$ and as it was shown in the experiment, greater spacing between plants is due to lower competition or larger leaf area of it, provided higher SBL as well as superior PSD when the greatest spacing between plants was used, in most of the evaluated seasons.

Evaluating the development of the passion fruit grafted and ungrafted, using the advanced seedlings technique, in Presidente Prudente, SP, Cavichioli et al. (2017) observed stem diameter for the ungrafted close to this experiment, $13.6 \mathrm{~mm}$ at the 180 DAT. There are few data in the literature on spacing effect on the vegetative development of advanced passion fruit seedlings in the field, since it is a recent technique ( 5 years) for the coexistence with HFV and is not yet employed throughout the country.

The absence of $\mathrm{N}$ dose effect for the PSD is contradictory to the result observed by Silva et al. (2016), these authors evaluating the effect of humic substances (HS) and $\mathrm{N}$ in the semiarid observed the quadratic dose effect for the stem diameter in traditional seedling. At 270 DAT, we observed a maximum value of $28.1 \mathrm{~mm}$ using an $\mathrm{N}$ dose of $281.3 \mathrm{~kg} \mathrm{ha}^{-1}$. According to these authors, the positive response to the $\mathrm{N}$ dose can be attributed to the low organic matter content (O.M.) present in the soil 12.1 $\mathrm{g} \mathrm{dm}^{-3}$, different from the present experiment that studied $\mathrm{N}$ dose in soil with higher O.M., $31.0 \mathrm{~g} \mathrm{dm}^{-3}$.

Bertani et al. (2019) also observed the effect of the $\mathrm{N}$ dose increase in the PSD as well as in the PSL in advanced passion fruit seedlings. $\mathrm{N}$ influence on the PSD was verified in the evaluations at 60, 75, 90 days after the emergency (DAE), while at 45 DAE was not significant. Possibly the low initial demand of the passion fruit plant was supplied by the substrate, which presented O.M. superior to the present experiment soil. The PSL was influenced by the $\mathrm{N}$ dose in all evaluation seasons, showing that not all vegetative characteristics responds in the same way to nitrogen fertilization.

For the production and number of fruits per plant (NFP), productivity, number of thousand fruits per hectare (NThFH) and percentage of commercial fruits, interaction of $\mathrm{N}$ doses and spacing between plants were not observed. However, it was verified the isolated effect of $\mathrm{N}$ dose for production per plant and spacing effect for all production characteristics, except percentage of commercial fruits. The increase of $\mathrm{N}$ dose provided quadratic polynomial increase in the production, with an estimated maximum of $15.4 \mathrm{~kg}$ of fruit $\mathrm{pl}^{-1}$ with $130.7 \mathrm{~kg} \mathrm{ha}^{-1}$ of $\mathrm{N}$ (Figure 2).

About the effect of $\mathrm{N}$ on the productive characteristics, Moura et al. (2016) and Silva et al. (2016) also observed effect for production, they verified maximum of $13.4 \mathrm{~kg}$ plant $^{-1}$ using $268.1 \mathrm{~kg} \mathrm{ha}^{-1}$ of $\mathrm{N}$ and of $14.4 \mathrm{~kg}_{\text {plant }}{ }^{-1}$ with $290 \mathrm{~kg} \mathrm{ha}^{-1}$, respectively. Unlike the current experiment, these authors also verified $\mathrm{N}$ effect for productivity, Moura et al. (2016) verified $14.9 \mathrm{t} \mathrm{ha}^{-1}$ with 
$268.5 \mathrm{~kg} \mathrm{ha}^{-1}$ and Silva et al. (2016) reported maximum of $16.5 \mathrm{t} \mathrm{ha}^{-1}$, with $290 \mathrm{~kg} \mathrm{ha}^{-1}$ of N. Borges et al. (2006) verified only interaction between source and $\mathrm{N}$ doses for productivity, estimating maximum of $41.3 \mathrm{tha}^{-1}$ with application of $483 \mathrm{~kg} \mathrm{ha}^{-1}$ of $\mathrm{N}$ with the urea source and minimum productivity of $32.8 \mathrm{t} \mathrm{ha}^{-1}$ with $228 \mathrm{~kg} \mathrm{ha}^{-1}$ of
$\mathrm{N}$ from the calcium nitrate. The difference in $\mathrm{N}$ dose for maximum passion fruit production may depend on several factors, such as climate, soil fertility, cultivar, seedlings, cultivation period, handling, HFV incidence and severity, among others.

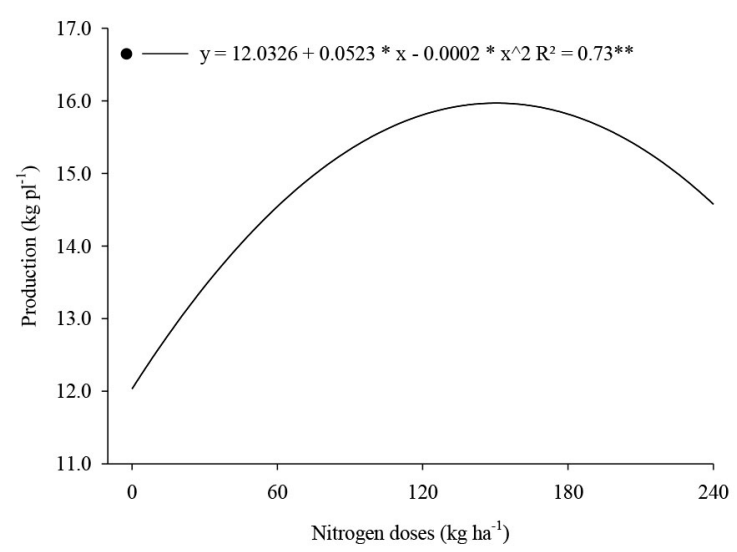

Figure 2. Passion fruit production, in $\mathrm{kg} \mathrm{pl}^{-1}$, according to nitrogen doses in coverage $0 ; 60 ; 120 ; 180$ and $240 \mathrm{~kg} \mathrm{ha}^{-1}$. Mogi Mirim, SP, October 2017 to July 2018. **Significant at $1 \%$ probability by F test.

In contrast, Venâncio et al. (2013), Miyake et al. (2016) and Dias et al. (2016) observed the lack of response to the increase with N. Venâncio et al. (2013), in a 6-month harvest period, reported mean of $27.7 \mathrm{~kg} \mathrm{plant}^{-1}$ and 164.1 fruits per plant, while Miyake et al. (2016) reported higher average production $28.6 \mathrm{~kg} \mathrm{plant}^{-1}$, in an area without HFV, and in traditional cultivation Dias et al. (2017) verified $20.7 \mathrm{~kg} \mathrm{plant}^{-1}$ and 133.7 fruits per plant. These results agree in part with those obtained in this study, according to these authors, possibly the high soil fertility, the planting fertilization or cultural remains may have masked the efficiency of the nitrogenized fertilizer and/or the element was not a limiting factor in the experimental conditions.

Studying the N decomposition and release of organic waste, Silva et al. (2014) observed that chicken manure presented the highest decomposition speed and the second largest $\mathrm{N}$ release to the soil. They estimated that the application of $20 \mathrm{t} \mathrm{ha}^{-1}$ of chicken bed, could release $103.5 \mathrm{~kg} \mathrm{ha}^{-1}$ of $\mathrm{N}$ after 270 days of application. It is also emphasized that the fruit cultivation is common for several years in the same site, due to the use of laborious and costly conduction system such as for passion fruit cultivation. Thus, it is common to occur fertilization overlap and the fruit cultivation in a soil with high nutrient content.
The present study has also showed that dose greater than $130 \mathrm{~kg} \mathrm{ha}^{-1}$ of $\mathrm{N}$, can be harmful to fruit production, agreeing with the results of Borges et al. (2006), Venâncio et al. (2013), Dias et al. (2016) and Moura et al. (2016). These authors reported that when the $\mathrm{N}$ is applied above the recommended, the vegetative growth is favored at the expense of the number of flowers.

As for the spacing effect on the production and in the NFP, these were higher using the $4.0 \mathrm{~m}$ spacing between plants, $16.6 \mathrm{~kg} \mathrm{pl}^{-1}$ and 99.7 fruits per plant, respectively. For the productivity and $\mathrm{NThFH}$, it was observed inverse effect, $20.7 \mathrm{t} \mathrm{ha}^{-1}$ and 139.5 thousand fruits ha ${ }^{-1}$ when used the highest density (Table 4). Spacing did not influence the percentage of commercial fruits, and the average value is $81.5 \%$. 
Table 4. Production, number of fruits per plant (NFP), productivity, number of thousand fruits per hectare (NThFH), fruit mass and longitudinal length (LL), related to the spacing between passion fruit plants, 2.0 and $4.0 \mathrm{~m}$ between plants and 3.0 between lines. Mogi Mirim, SP, October 2017 to July 2018.

\begin{tabular}{lcccccc}
\hline \multicolumn{1}{c}{ Spacing } & Production & NFP & Productivity & NThFH & Fruit mass & LL \\
\hline $\mathrm{m}$ & $\mathrm{kg} \mathrm{pl}^{-1}$ & $\mathrm{n}^{\mathrm{o}} \mathrm{pl}^{-1}$ & $\mathrm{t} \mathrm{ha}^{-1}$ & $\mathrm{n}^{\mathrm{o}} \mathrm{mil} \mathrm{ha}^{-1}$ & $\mathrm{~g}$ & $\mathrm{~cm}$ \\
\hline 2 & $12.4 \mathrm{~b}$ & $83.7 \mathrm{~b}$ & $20.7 \mathrm{a}$ & $139.5 \mathrm{a}$ & $165.0 \mathrm{~b}$ & $8.3 \mathrm{~b}$ \\
4 & $16.6 \mathrm{a}$ & $99.7 \mathrm{a}$ & $13.8 \mathrm{~b}$ & $83.1 \mathrm{~b}$ & $170.4 \mathrm{a}$ & $8.5 \mathrm{a}$ \\
\hline $\mathrm{dms}$ & 2.1 & 13.5 & 2.2 & 12.8 & 4.9 & 0.1 \\
$\mathrm{CV} \%$ & 22.1 & 21.9 & 19.2 & 17.0 & 4.4 & 2.7 \\
\hline
\end{tabular}

Column means, followed by the same letter, do not differ from each other by Tukey test at $5 \%$ probability.

The results agreed with the statement of Cavichioli et al. (2014), that the lowest number of fruits per plant in the densest spacing resulting from the increase of the competition between plants is compensated by the higher productivity. This relationship was also confirmed by Ritzinger et al. (1987), Andrade Júnior et al. (2003), and Araújo Neto et al. (2005) for NFTP.

Maximum response for productivity and NThFH of $49.3 \mathrm{tha}^{-1}$ and 702.0 thousand $\mathrm{ha}^{-1}$, respectively, obtained in the lowest spacing, $2.5 \times 2.0 \mathrm{~m}\left(2,000 \mathrm{ha}^{-1}\right.$ plants $)$ were reported by Ritzinger et al. (1987). Andrade Júnior et al. (2003) observed quadratic effect on the productivity with the increase of the density from 830 to 3,330 plants $\mathrm{ha}^{-1}(3.0 \times 4.0 \mathrm{~m}$ to $3.0 \times 1.0 \mathrm{~m})$; they concluded the maximum productivity with 1,841 plants $\mathrm{ha}^{-1}(3.0 \times 1.8$ $\mathrm{m})$. These same authors concluded, however, that the highest economic production occurred in the $3.0 \times 2.5$ m spacing. Araújo Neto et al. (2005) recommended the density of 1,110 plants per hectare $(3.0 \times 3.0 \mathrm{~m})$, being more productive and lucrative than the traditional spacing $(3.0 \times 5.0 \mathrm{~m})$ or the super dense planting $(3.0 \times 1.0 \mathrm{~m})$.

Evaluating planting density in the area with the incidence of the HFV, Cavichioli et al. (2014), observed a similar result to the present experiment. Higher productivity in the densest spacing $(3.2 \times 1.0 \mathrm{~m}), 14.55 \mathrm{t}$ $\mathrm{ha}^{-1}$, differing from the $3.2 \times 5.0 \mathrm{~m}$, with $4.32 \mathrm{t} \mathrm{ha}^{-1}$. These authors calculated maximum productive efficiency per plant using $3.2 \times 3.8 \mathrm{~m}$.

Weber et al. (2016) also verified the directly proportional relationship NThFH and the productivity with the planting density, for plants of one-year cultivation cycle, in two evaluations. Production of 25.4 and 19.2 $\mathrm{t} \mathrm{ha}^{-1}$ and number of fruits 31.8 and 24.9 plant $^{-1}$, were obtained in the $2.5 \times 2.5 \mathrm{~m}$ spacing with two seedlings per hole (3,200 plants ha-1) in the 2011/2012 and 2012/2013 harvest. Differently, for the two-year plant, these same authors did not observe significant effect for the NThFH and productivity characteristics, with the means of 99.1 thousand fruits plant ${ }^{-1}$ and $24.1 \mathrm{t} \mathrm{ha}^{-1}$. According to the authors, a possible cause would be the high vigor in the highest density, along with spray difficulties within the plant and high shading of the productive branches.
The passion fruit crop presents a productive potential of 40-50 t ha-1, in traditional cultivation with 2-year cycle (MELETTI, 2011). However, the hardening fruit virus (HFV) has caused great losses in infected plants, which have their production reduced quantitatively and qualitatively (CAVICHIOLI et al., 2014). The productivity reduction can be severe; Cavichioli et al. (2011) observed average productivity of $30.9 \mathrm{t} \mathrm{ha}^{-1}$ in passion fruit plants grafted in the year of 2006/2007 in Adamantina, SP. While in 2009/2010 in the same location, Cavichioli et al. (2014), using the same spacing $(3.2 \times 5.0 \mathrm{~m})$ and graft canopy combination, but reporting high incidence of HFV obtained $4.3 \mathrm{tha}^{-1}$, without the use of advanced seedlings. Cavichioli et al. (2016) also observed a 32\% reduction in the productivity when compared with Cavichioli et al. (2011) study, before the incidence of the virus.

Evaluating the economic return using different NPK doses for passion fruit plants, Miyake et al. (2016) obtained average productivity of $43 \mathrm{t} \mathrm{ha}^{-1}$, in virus-free area, with advanced seedlings and annual cultivation. Miyake et al. (2018) also performing an experiment using the same nutritional management, but reporting high incidence and severity of the HFV, obtained lower maximum productivity, $19.8 \mathrm{tha}^{-1}$ with a dose of $300 \mathrm{~kg}$ $\mathrm{N} \mathrm{ha}^{-1}$. Also with advanced seedlings in the area with the presence of the HFV, studying accumulation and export of nutrients by passion fruit plant, Mattar et al. (2018) verified productivity of $17.0 \mathrm{t} \mathrm{ha}^{-1}$ and production of $20.4 \mathrm{~kg} \mathrm{pl}^{-1}$. The authors estimated extraction of $148.7 \mathrm{~kg} \mathrm{ha}^{-1}$ of $\mathrm{N}$.

Thus, despite the productivity of the current experiment reach $17.3 \mathrm{t} \mathrm{ha}^{-1}$ and it is not the potential of the crop in the traditional cultivation, it is very close to that observed by other studies implanted in the region with incidence of the virus, using the management technique for coexistence with the virus, advanced seedlings and annual cycle. It is also noteworthy, that the transplantation of the present experiment occurred in October, which caused delay in the beginning of the flowering that occurred in January. Thus, the harvest period was on average $30 \%$ lower, totaling 5 months, compared the annual harvest when the transplantation is in August and harvest period occurs between the end of December/ beginning of January until July, approximately 7 months. 
In addition to the productive question, the analysis of the economic performance is also important. Moreira et al. (2019) evaluating the profitability of the passion fruit plant with the increase of the cultivation density, concluded that the lowest tested spacing $2.0 \times 3.0 \mathrm{~m}$ provided the highest profitability in two years of production, exceeding in $51.4 \%$ the income that can be achieved using the $5.0 \mathrm{x}$ $3.0 \mathrm{~m}$ spacing, traditional in the passion fruit cultivation. Nearest value was found in the present study, the spacing of $2.0 \times 3.0 \mathrm{~m}$ was $49.3 \%$ higher than $4.0 \times 3.0 \mathrm{~m}$. Thus, we should pay attention to adopt the density that provides the highest economic benefit to the producer, taking into account the particularities of the producing region.

Currently, besides the concern with the overlap of productive branches and profitability caused by the highest density, the new dynamics of passion fruit cultivation should be added for coexistence with the HFV, reduction of the crop cycle and the search for maximum productivity in only one harvest. Costa et al. (2008) recommend the reduction of the spacing between plants of $3.0 \times 5.0 \mathrm{~m}$ $\left(666\right.$ plants ha $\left.^{-1}\right)$, to $3.0 \times 2.0 \mathrm{~m}\left(1,666\right.$ plants ha $\left.{ }^{-1}\right)$ in the State of Espírito Santo. On the other hand, for the State of São Paulo, Narita et al. (2012) indicate at most 2.5 $\mathrm{m}$ between plants in the line, while for the State of the Paraná Stenzel et al. (2019) suggest the spacing of 2.0 and $2.5 \mathrm{~m}$ in the lines and 2.5 to $3.5 \mathrm{~m}$ between lines. These recommendations agree with the results obtained in the experiment, where the productivity and $\mathrm{NThFH}$ were at least $43 \%$ higher when we used $3.0 \times 2.0 \mathrm{~m}$, however, scientific studies on spacing in areas affected by the virus are still scarce, which makes it difficult to recommend.

For the fruit characteristics, isolated effects of $\mathrm{N}$ dose for the transversal length (TL), which increased in a quadratic manner, with the estimated maximum value $7.4 \mathrm{~cm}$ with $99.0 \mathrm{~kg}$ of $\mathrm{N} \mathrm{ha}^{-1}$ (Figure 2A). The spacing influenced the mass and longitudinal length (LL) of the fruit, which were higher in the least dense plants, respectively $170.4 \mathrm{~g}$ and $8.5 \mathrm{~cm}$ (Table 4). The average caliber of the fruit was classified in class 3 , because the value of the LL was in the range equal to or greater than $6.5 \mathrm{~cm}$ and less than $7.5 \mathrm{~cm}$ (CEAGESP, 2001).

The $\mathrm{N}$ effect on fruit quality on passion fruit plants has been studied; however, there are few studies and the results showed divergent responses (AULAR et al., 2014). Testing the irrigation depth, Carvalho et al. (2000) also reported that $\mathrm{N}$ did not influence the fruit mass, obtaining average close $161 \mathrm{~g}^{\text {fruit }}{ }^{-1}$. In the north region of Minas Gerais, Borges et al. (2003), working with nitrogen and potassium interaction $(\mathrm{K})$ only verified significant effect of K. In new study, Borges et al. (2006) also did not verify influence of the $\mathrm{N}$ fertilization as well as of the sources used in the physical characteristics of the fruit.

In recent studies, Silva et al. (2015) and Dias et al. (2017) did not verify N effect on physical characteristics of the fruit, agreeing in part with the obtained results. Silva et al. (2015) verified higher mean values regarding to the present experiment for mass, fruit LL and TL, respectively, $205.8 \mathrm{~g}, 9.6 \mathrm{~cm}$ and $7.9 \mathrm{~cm}$, however lower pulp yield 38.4 $\%$. Dias et al. (2017) reported the following mean, fruit mass $163.2 \mathrm{~g}$, LL $9.83 \mathrm{~cm}$ and TL $7.63 \mathrm{~cm}$ and pulp yield of $54.2 \%$. Moura et al. (2016) different from the present study, reported interaction between $\mathrm{N}$ source and dose for pulp percentage with maximum values of $52.7 \%$ using the urea and $48.5 \%$ with ammonia sulfate. All of these pulp yield values are lower than found, possibly this is due to the use purpose or cultivar commercialization used. The IAC 10 cultivar was improved to meet the industry segment, so high pulp yield is an important characteristic.

Venâncio et al. (2013) observed effect of the doses for fruits mass and LL. These authors verified quadratic relationship for mass, with maximum value of $175.7 \mathrm{~g}$ with dose of $86 \mathrm{~kg} \mathrm{ha}^{-1}$, while for fruit LL linear increasing response, with $91.5 \mathrm{~mm}$ for dose of $210 \mathrm{~kg} \mathrm{ha}^{-1}$. Miyake et al. (2018) observed $\mathrm{N}$ dose effect only in fruits classified as caliber 4, higher when they used dose of $150 \mathrm{~kg}$ of $\mathrm{N} \mathrm{ha}^{-1}$. These results differ from those obtained in this experiment, showing that other factors besides the $\mathrm{N}$ dose can influence in the fruits physical characteristics. Aguiar et al. (2017) observed different responses at the application of bovine biofertilizer dose according to the evaluated genotype.

Although the increase in fruit TL by $\mathrm{N}$ did not result in increase of the caliber in the present experiment, this result can be interesting to the producer, because the higher the caliber, the more valued the fruit is. Studies were not found in the literature about this relationship, thus, it is necessary more studies on this characteristic for commercialization.

Cavichioli et al. (2016) verified linear response for LL with the reduction of plant density with maximum diameter $11.2 \mathrm{~cm}$ in the highest spacing used $5.0 \mathrm{~m}$. For fruit mass, the authors did not observe spacing effect, different from the present study, with the mean being close to that found of $183.4 \mathrm{~g}$. Several authors reported absence of density effect on fruit mass (ANDRADE JÚNIOR et al. 2003; ARAÚJO NETO et al. 2005; WEBER et al. 2016). According to Manica et al. (1994), the passion fruit genetics is responsible for the highest fruiting, at the expense of the increase of fruit mass. Nascimento et al. (2003) cites that there is a great variability in the fruit size in the same plant and in the same genotype. It is important to highlight, that many of these studies were performed before the use of the advanced seedlings technique and with other cultivars, and thus can affect in the qualitative dynamics of the passion fruit. However, it is observed that this difference in fruit mass between spacing despite significant was small, becoming clear that the passion fruit productivity is more influenced by the number of fruits than the average mass of these, agreeing with other studies. 
For the physico-chemical characteristics of the fruit, there was significant interaction in the ascorbic acid content (AAC) and $\mathrm{N}$ isolated effect for the soluble solids content (SS) and total acidity (TA) (Figure 3). In the interaction unfolding, quadratic regression was verified for the $2.0 \mathrm{~m}$ and linear spacing for the highest spacing
(Figure 3B). The content of $30.6 \mathrm{mg}$ of ascorbic acid 100 $\mathrm{mL}^{-1}$ was estimated applying the dose of $188 \mathrm{~kg} \mathrm{ha}^{-1}$ of N for the lowest spacing, while for $4.0 \mathrm{~m}$ between plants, the maximum dose tested, $240 \mathrm{~kg} \mathrm{ha}^{-1}$ of $\mathrm{N}$, provided the highest AAC $35.3 \mathrm{mg} 100 \mathrm{~mL}^{-1}$. Mean value of 2.9 for the $\mathrm{pH}$ and 3.8 for ratio was observed.
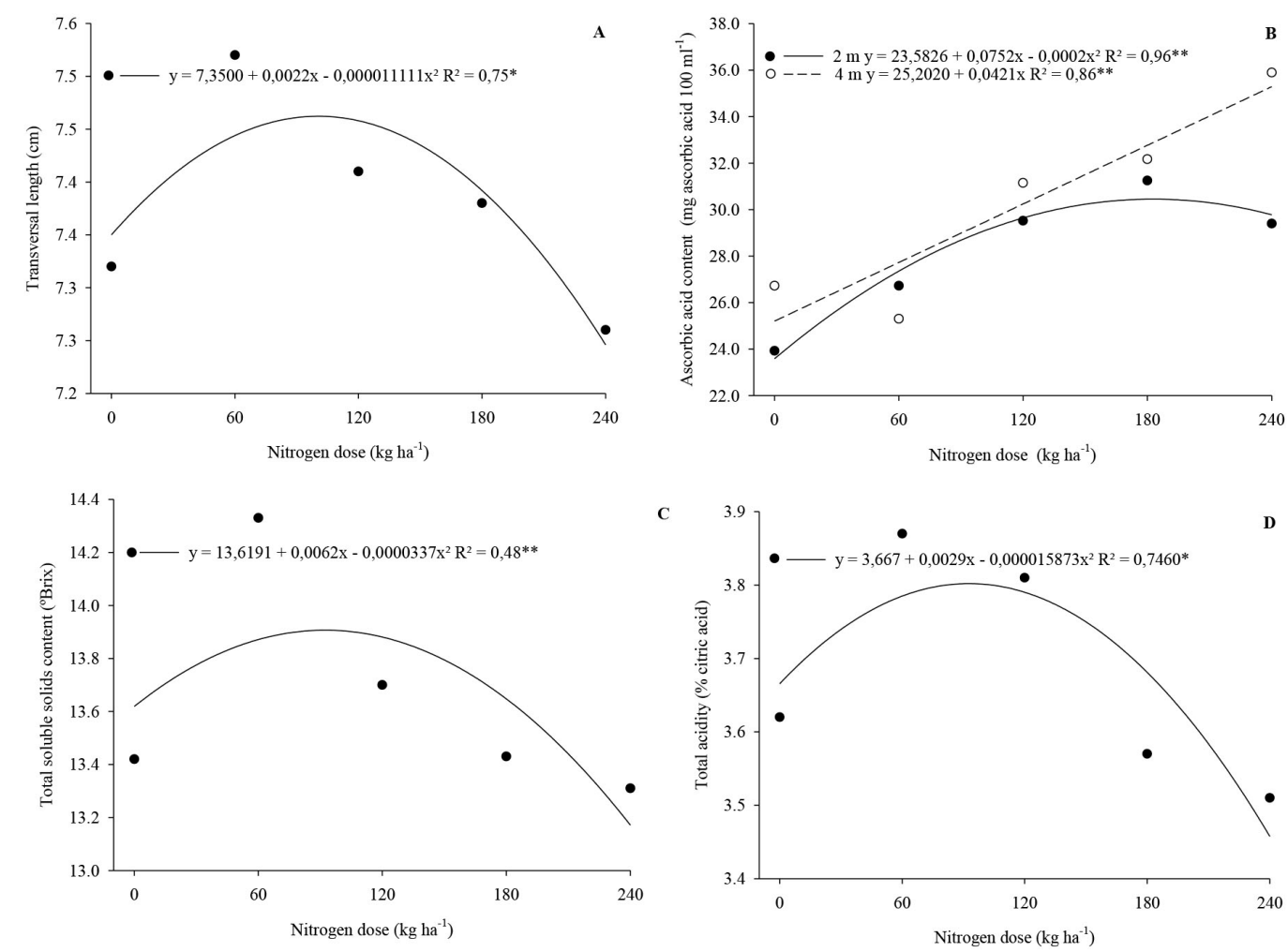

Figure 3. Ascorbic acid content (b) according to nitrogen $(\mathrm{N})$ dose in coverage $0 ; 60 ; 120 ; 180$ and $240 \mathrm{~kg} \mathrm{ha}^{-1}$ and the spacing between passion fruit plants, 2.0 and $4.0 \mathrm{~m}$ between plants and 3.0 between lines and fruit transversal length (a), total soluble solids content (c) and total acidity (d) depending on the N doses. Mogi Mirim, SP, October 2017 to July $2018 .{ }^{* *}$ Significant at $1 \%$ probability by $\mathrm{F}$ test; $*$ Significant at $5 \%$ probability by $\mathrm{F}$ test.

Sousa et al. (2020) observed maximum value of $20.6 \mathrm{mg}$ of ascorbic acid $100 \mathrm{~g}^{-1}$ with dose close to $198 \mathrm{~kg}$ $\mathrm{ha}^{-1}$ of $\mathrm{N}$. The increase of the biofertilizer dose for cultivars 'Guinezinho' and 'Sol do Cerrado' also resulted in AAC reduction, with the maximum $39.7 \mathrm{mg} 100 \mathrm{~mL}^{-1}$ and 45.66 $\mathrm{mg} 100 \mathrm{~mL}^{-1}$ for dose 19.3 and $17.7 \%$, respectively. While for the 'Gigante amarelo' the maximum concentration 26.3 $\mathrm{mg} 100 \mathrm{~mL}^{-1}$ of ascorbic acid occurred using the maximum dose, $40 \%$ of biofertilizer (AGUIAR et al., 2017).

Studying the effect between $\mathrm{N}$ doses and humic substance (HS), Silva et al. (2015) did not observe effect in the AAC, they verified mean value $29.62 \mathrm{mg} 100 \mathrm{~mL}$ 1. Carvalho et al. (2000) also did not observe effect for vitamin $\mathrm{C}$, with an average of $16.9 \mathrm{mg} 100 \mathrm{~mL}^{-1}$.

Regarding the spacing, Sousa et al. (2020) verified the increase of AAC as increased the number of plants per hole, the density. They found values 16.0 to $27.3 \mathrm{mg} 100$ $\mathrm{mL}^{-1}$, using from 1 to 6 plants per hole with spacing of $2.5 \times 3.0 \mathrm{~m}$ between holes.
For the SS, the maximum value was $13.9^{\circ} \mathrm{Brix}$ using the dose of $93.3 \mathrm{~kg} \mathrm{ha}^{-1}$ of $\mathrm{N}$ (Figure 3C). While the maximum TA $3.7 \%$ of citric acid was verified with dose of $91.3 \mathrm{~kg} \mathrm{ha}^{-1}$ of N (Figure 3D). Decrease trend in SS and TA with the increase of biofertilizer doses agrees with the results of Aguiar et al. (2017), except for 'Guinezinho' in the TA. Silva et al. (2015) also noticed exponential decrease of the TA value due to the increase of $\mathrm{N}$ doses in the absence of HS.

Venâncio et al. (2013) who did not observe $\mathrm{N}$ effect for SS, TA and ratio, with the mean values, respectively,

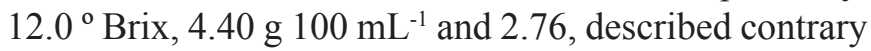
result. Effect absence for these variables besides the $\mathrm{pH}$, was also reported by Moura et al. (2016). These authors observed the following means: SS of $12.8^{\circ} \mathrm{Brix}$ and AAC of $2.13 \mathrm{~g} 100 \mathrm{~mL}^{-1}, \mathrm{pH} 6.10$ and ratio $2.8 \%$. These results differ from those observed in the present research, except for $\mathrm{pH}$ and ratio. 
The planting density also did not affect the fruit quality according to Andrade Junior et al. (2003), Araujo Neto et al. (2005) and Weber et al. (2016). Possibly the plant genetic constitution influences more in the juice chemical characteristics than the management used.

\section{Conclusion}

The dose found for maximum production, $15.4 \mathrm{~kg}$ of fruit $\mathrm{pl}^{-1}$, and adequate fruit physico-chemical quality by the passion fruit plant was of $130.7 \mathrm{~kg} \mathrm{ha}^{-1}$ of $\mathrm{N}$.

The most densified spacing, of $2 \times 3 \mathrm{~m}$, provided higher productivity and number of fruits per hectare, respectively, $20.7 \mathrm{t} \mathrm{ha}^{-1}$ and 139.5 thousand fruits $\mathrm{ha}^{-1}$.

\section{Acknowledgments}

The current study was conducted with support of the Coordination for the Improvement of Higher Education Personnel - Brazil (CAPES) - Funding Code 001 and of the São Paulo Research Foundation (FAPESP) - (FAPESP-2017/12086-8).

The authors would also like to thank the producer Esdras Olinto Prado Vilhena for collaboration in the project execution.

\section{References}

AGUIAR, A.V.M.; CAVALCANTE, L.F.; SILVA, R.M.; DANTAS, T.A.G.; SANTOS, E.C. Effect of biofertilization on yellow passion fruit production and fruit quality. Revista Caatinga, Mossoró, v.30, n.1, p.136-148, 2017.

ANDRADE, J.M. de B.; BRANDÃO FILHO, J.E.T.; VASCONCELOS, M.A. da S. Efeito da densidade de plantio no primeiro ano de produção do maracujazeiroamarelo, no noroeste do Paraná. Revista Brasileira de Fruticultura, Jaboticabal, v.16, n.2, p.49-54, 1994.

ANDRADE JUNIOR, V.C. de; ARAÚJO NETO, S.E.; RUFINI, J.C.M.; RAMOS, J.D. Produção de maracujazeiro-amarelo sob diferentes densidades de plantio. Pesquisa Agropecuária Brasileira, Brasília, DF, v.38, n.12, p.1381-1386, 2003.
ARAÚJO NETO, S.E. de; RAMOS, J.D.; ANDRADE JÚNIOR, V.C. de; RUFINI, J.C.M.; MENDONÇA, V.; OLIVEIRA, T.K. de. Adensamento, desbaste e análise econômica na produção do maracujazeiro-amarelo. Revista Brasileira de Fruticultura, Jaboticabal, v.27, n.3, p.394-398, 2005.

AULAR, J.; CASARES, M.; NATALE, W. Nutrição mineral e qualidade do fruto do abacaxizeiro e do maracujazeiro. Revista Brasileira de Fruticultura, Jaboticabal, v.36, n.4, p.1046-1054, 2014.

BERTANI, R.M. de A.; SILVA, S.P. da.; DEUS, A.C.F.; ANTUNES, A.M.; FISCHER, I.H. Doses de nitrogênio no desenvolvimento de mudas altas de maracujá-amarelo. Journal of Neotropical Agriculture, Cassilândia, v.6, n.1, p.29-35, 2019.

BORGES, A.L.; CALDAS, R.C.; LIMA, A.A. Doses e fontes de nitrogênio em fertirrigação no cultivo do maracujá-amarelo. Revista Brasileira Fruticultura, Jaboticabal, v.28, n.2, p.301-304, 2006.

BORGES, A.L.; RODRIGUES, M.G.V.; LIMA, A.de A.; ALMEIDA, I.E. de; CALDAS, R.C. Nitrogen and potassium effects on yield and quality of yellow passion fruit, under irrigation. Revista Brasileira de Fruticultura, Jaboticabal, v.25, n.2, p.259-262, 2003.

CARVALHO, A.J.C.; MARTINS, D.P.; MONNERAT, P.H.; BERNARDO, S. Adubação nitrogenada e irrigação no maracujazeiro-amarelo. I Produtividade e qualidade dos frutos. Pesquisa Agropecuária Brasileira, Brasília, DF, v.35, n.6, p.1101-1108, 2000.

CAVICHIOLI, J.C.; CORRÊA, L.S.; BOLIANI, A.C.; SANTOS, P.C. dos. Desenvolvimento e produtividade do maracujazeiro-amarelo enxertado em três porta-enxertos. Revista Brasileira de Fruticultura, Jaboticabal, v.33, n.2, p.558-566, 2011.

CAVICHIOLI, J.C.; KASAI, F.S. ; NASSER, M.D. Produtividade e características físicas de frutos de Passiflora edulis enxertado sobre Passiflora gibertii em diferentes espaçamentos de plantio. Revista Brasileira de Fruticultura, Jaboticabal, v.36, n.1, p.243-247, 2014. 
CAVICHIOLI, J.C.; NARITA, N.; NASSER, M.D.; TAKATA, W.H.S. Desenvolvimento e produtividade de maracujazeiro amarelo enxertado na região de presidente prudente, SP. Cultura Agronômica, Ilha Solteira, v.26, n.1, p.61-68, 2017.

CAVICHIOLI, J.C.; NASSER, M.D.; VITORINO, R.A. Produtividade e características físicas de frutos de maracujazeiro amarelo enxertado em diferentes espaçamentos de plantio. Magistra, Cruz Das Almas, v.28, n.3/4, p.456-462, 2016.

CEAGESP- Companhia de Entrepostos e Armazéns Gerais de São Paulo. Classificação do maracujá (Passiflora edulis ims). São Paulo: Programa Brasileiro para a Melhoria dos Padrões Comerciais e de embalagens do Maracujá-Azedo, 2001. Disponível em: http://www. ceagesp.com.br. Acesso em: 07 dez. 2020.

COSTA, A. de F.S. da; COSTA, A.N. da; VENTURA, J.A.; FANTON, C.J.; LIMA, I. de M.; CAETANO, L. C. S.; SANTANA, E. N. de. Recomendações técnicas para o cultivo do maracujazeiro. Vitória: INCAPER. 2008. p.56.

DIAS, D.G.; PEGORARO, R.F.; MAIA, V.M.; MEDEIROS, A.C. Production and postharvest quality of irrigated passion fruit after n-k fertilization. Revista Brasileira Fruticultura, Jaboticabal, v.39, n.3, e-553, 2017.

DAMATTO JUNIOR, E.R.; FUZITANI, E.J.; NOMURA, E.S. Produção de maracujá com uso de mudas avançadas no Vale do Ribeira. Revista Pesquisa \& Tecnologia, Campinas, v.11, n.1, p.1-6, 2014.

FURLANI, P.R.; PURQUERIO, L.F.V. Avanços e desafios na nutrição de hortaliças. In: MELLO PRADO, R.; CECILIO FILHO, A.B.; CORREIA, M.A.R.; PUGA, A.P. (org.). Nutrição de plantas: diagnose foliar em hortaliças. Jaboticabal: FCAV, 2010. p.45-62.

GIORIA, R.; BOSQUÊ, G.G.; REZENDE, J.A.M.; AMORIM, L.; KITAJIMA, E.W. Incidência de viroses de maracujazeiro na Alta Paulista - SP, e danos causados pelo "Passionf fruit woodiness vírus". Fitopatologia Brasileira, Brasília, DF, v.25, p.182-189, 2000.
HAAG, H.P.; OLIVEIRA, G.D.; BORDUCCHI, A.S.; SARRUGE, J.R. Absorção de nutrientes por duas variedades de maracujá. Anais da Escola Superior de Agricultura Luiz de Queiroz, Piracicaba, v.30, p.267279, 1973.

IAL - Instituto Adolfo Lutz. Métodos físico-químicos para análise de alimentos. São Paulo: Instituto Adolfo Lutz, 2008. p.1020.

IBGE - Instituto Brasileiro de Geografia e Estatística. Produção agrícola municipal. Rio de Janeiro, 2019. Disponível em: https://sidra.ibge.gov.br/tabela/5457. Acesso em: 20 abr. 2021.

MANICA, I.; FIORAVANÇO, J.C.; BARRADAS, C.I.N.; KITS, H. Seis espaçamentos de plantio e produção do maracujazeiro-amarelo (Passiflora edulis f. flavicarpa Deg.) em Porto Lucena, RS. Pesquisa Agropecuária Brasileira, Brasília, DF, v.29, n.7, p.1083-1090, 1994.

MATTAR, G.S.; MORAES, C.C. de; MELETTI, L.M.M.; PURQUERIO, L.F.V. Accumulation and exportation of nutrients by yellow Passion fruit cv. IAC 275. Revista Brasileira de Fruticultura, Jaboticabal, v.40, n.3, p.e-178, 2018.

MELETTI, L.M.M. Avanços na cultura do maracujá no Brasil. Revista Brasileira de Fruticultura, Jaboticabal, v.33, p.83-91, 2011.

MIYAKE, R.T.M.; FURLANETO, F.P.B.; NARITA, N.; TAKATA, W.H S.; CRESTE, J.E. Economic evaluation of different types of nutritional management in yellow passion fruit vines (Passiflora edulis Sims.). Australian Journal of Crop Science, Melbourne, v.10, n.11, p.1572-1577, 2016.

MIYAKE, R.T.M.; FURLANETO, F.P.B.; NARITA, N.; TAKATA, W.H.S.; CRESTE, J.E. Economic analysis of the production of yellow passion fruit in an area with virose incidence and fertilized with NPK. Journal of Agricultural Science, Ontario, v.10, n.5, p.303-311, 2018.

MOREIRA, R.A.; CRUZ, M.C.M.; SANTOS, A.M.; FERNANDES, D.R.; OLIVEIRA, J. Rentabilidade do maracujazeiro-amarelo com aumento da densidade de cultivo. Ciência Agrícola, Rio Largo, v.17, n.1, p.2330, 2019. 
MOURA, R.S.; RIBEIRO, A.A.; SIMEÃO, M.; SIMÃO, L.P.L.; SOUSA, D.R.; SILVA, E.M.; LIMA, C.J.G.S.; SILVA JUNIOR, G. B. Productivity and physico chemical quality of yellow passion-fruit cultivated under different nitrogen sources through fertigation. International Journal of Current Research, India, v.8, n.11, p.42003-42009, 2016.

NARITA, N.; YUKI, V.A.; NARITA, H.H.; HIRATA, A.C.S. Maracujá amarelo: tecnologia visando a convivência com o vírus do endurecimento dos frutos. Pesquisa \& Tecnologia, Campinas, v.9, n.1, p.1-7, 2012.

NASCIMENTO, A.V.S.; SANTANA, E.N.; BRAZ, A.S.K.;ALFENAS, P.F.; PIO-RIBEIRO, G.; ANDRADE, G.P.; CARVALHO, M.G.; ZERBINI, F.M. Cowpea aphid-borne mosaic vírus (CABMV) is widespread in passion fruit in Brazil and causes passionfruit woodiness disease. Archives of Virology, New York, v.151, n.9, 1797-1809, 2006.

NASCIMENTO, W.M.O.; TOMÉ, A.T.; OLIVEIRA, M. do S.P. de; MÜLLER, C.H.; CARVALHO, E.U. de. Seleção de progênies de maracujazeiro-amarelo (Passiflora edulis f. flavicarpa) quanto à qualidade de frutos. Revista Brasileira de Fruticultura, Jaboticabal, v.25, n.1, p.186-188, 2003.

NASSER, M.D.; CAVICHIOLI, J.C.; KASAI, F.S.; VITORINO, R. Desenvolvimento de maracujazeiroamarelo enxertado sobre maracujazeiro-doce em diferentes espaçamentos de plantio. Revista Brasileira de Fruticultura, Jaboticabal, v.33, n.spe1, p.638-642, 2011.

RAIJ, B. van; ANDRADE, J.C. de; CANTARELLA, H.; QUAGGIO, J.A. Análise química para avaliação da fertilidade de solos tropicais. Campinas: Instituto Agronômico, 2001. 285 p.

RIPARDO, A.K.S. Doses de NPK no desenvolvimento, produtividade e qualidade de frutos do maracujazeiro "Roxinho do Kênia". 2010. Dissertação (Mestrado em Horticultura) - Faculdade de Ciências Agronômicas Universidade Estadual Paulista, Botucatu, 2010.

RITZINGER, R.; MANICA, I.; RIBOLDI, J. Efeito do espaçamento de plantio sobre a produção do maracujáamarelo em Viamão, RS. Pesquisa Agropecuária Brasileira, Brasília, DF, v.22, n.8, p.809-815, 1987.
PIZA JUNIOR, C. de T.; QUAGGIO, J.A.; MELETTI, L.M.M.; SILVA, J.R. da; SÃO JOSÉ, A.R.; KARATI, R. Maracujá. In: RAIJ, B. van; CANTARELLA, H.; QUAGGIO, J.A.; FURLANI, A.M.C. Recomendações de adubação e calagem para o Estado de São Paulo. 2.ed. Campinas: Instituto Agronômico/Fundação IAC, 1997. 285p. (Boletim Técnico, 100).

SANTOS, H.G. dos; JACOMINE, P.K.T.; ANJOS, L.H.C. dos; OLIVEIRA, V.A. de; LUMBRERAS, J.F.; COELHO, M.R.; ALMEIDA, J.A. de; ARAUJO FILHO, J.C. de; OLIVEIRA, J. B. de, CUNHA, T. J. F. Sistema brasileiro de classificação de solos. 5.ed. Brasília (DF): Embrapa, 2018. p.356.

SILVA, R.L.; CAVALCANTE, I.H.L.; LIMA, A.M.N.; BARBOSA, L.F.S.; SOUZA, C. de; SOUZA, E. dos S.; LESSA, T.B. da S.; CALVALCANTE, L.F. Effect of humic substances and nitrogen fertilization on yellow passion fruit cultivation in the Brazilian semiarid region. African Journal of Agricultural Research, Nairobi, v.11, n.35, p.3307-3313, 2016.

SILVA, V.B.; SILVA, A.P.; DIAS, B.O.; ARAUJO, J.P.; SANTOS, D.; FRANCO, R.P. Decomposição e liberação de N, P e K de esterco bovino e de cama de frango isolados ou misturados. Revista Brasileira de Ciência do Solo, Viçosa, MG, v.38, n.5, p.1537-1546, 2014.

SILVA, R.L.; CAVALCANTE, Í.H.L.; SOUSA, K.S.M.; GALHARDO, C.X.; SANTANA, E.A.; LIMA, D.D. Qualidade do maracujá amarelo fertirrigado com nitrogênio e substâncias húmicas. Comunicata Scientiae, Bom Jesus, v.6, n.4, p.479-487, 2015.

SOUSA, B.A.A. de; BEZERRA, F.T.C.; CAVALCANTE, L.F.;BEZERRA, M.A.F.; PEREIRA,W.E.P.; OLIVEIRA, I.C. dos S. Effect of population and organomineral fertilization on physico-chemical quality of fruits of Passiflora edulis cv. Guinezinho. Australian Journal of Crop Science, Melbourne, v.14, n.2, p.308-318, 2020.

STENZEL, N.M.C.; AULER, P.A.M.; MOLINA, R.O.; SOARES JUNIOR, D. Cultivo do maracujá-amarelo em área com ocorrência do vírus do endurecimento dos frutos (CABMV). Londrina: IAPAR, 2019. p.29. (Informe da Pesquisa, 161). 
VENÂNCIO J.B.; RODRIGUES E.T.; SILVEIRA M.V.; ARAÚJO W.F.; CHAGAS E.A.; CASTRO A.M. Produção, qualidade dos frutos e teores de nitrogênio foliar em maracujazeiro-amarelo sob adubação nitrogenada. Revista Científica, Jaboticabal, v.41, n.1, p.11-20, 2013.

WEBER, D.; ELOY, J.; GIOVANAZ, M.A.; FACHINELLO, J.C.; NACHTIGAL, J.C. Densidade de plantio e produção do maracujazeiro-azedo no sul do Brasil. Revista Brasileira de Fruticultura, Jaboticabal, v.38, n.1, p.99-106, 2016.
YUKI, V.A.; MIZOTE, F.A.; NARITA, N.; HOJO, H.; DELFINO, M.A.; OLIVEIRA, D.A. Epidemiologia do vírus do endurecimento dos frutos do maracujazeiro na região produtora da alta Paulista-SP. Summa Phytopathologica, Botucatu, v.32, p.19, 2006. Suplemento 